\title{
FAKTOR PREDIKTOR LUARAN DISABILITAS PADA PASIEN STROKE ISKEMIK DI RUMAH SAKIT BETHESDA YOGYAKARTA
}

\author{
PREDICTING FACTOR FOR DISABILITY OUTCOME IN PATIENT WITH \\ ISCHEMIC STROKE IN BETHESDA HOSPITAL YOGYAKARTA
}

Irene Gracia Wijayanti, * Rizaldy Taslim Pinzon, * Esdras Ardi Pramudita*

\section{ABSTRACT}

Introduction: It is estimated that around $25 \%$ to $74 \%$ of the 50 million stroke patients who live become independent either need the full or partial assistance due to decreased physical abilities, cognition, and emotions.

Aims: The aim of this study is to measure the determinant factors for disability in patients with ischemic stroke.

Methods: Cohort retrospective study using stroke registry and medical records on stroke patients in Bethesda Hospital, Yogyakarta, from 2015 to 2017. The inclusion criteria included patients $\geq 40$ years old, that has been diagnosed with ischemic stroke using CT scan, had complete stroke registry data and medical record. For the analysis this study used univariate, Chi-square method for bivariate, and logistic regression method for multivariate analysis.

Results: Based on multivariate analysis, muscle strength $0-4(p=0.023), 3(p=0.267), 2(p=0.579)$, and $1(p=0.049)$, $0(p=0.003)$ ), also aphasia $(p<0.001)$, dysphagia $(p<0.001)$, and triglyceride levels $(p=0.043)$ were significant predictors of disability outcomes in patients with ischemic stroke.

Discussion: Motor strength, aphasia, dysphagia, and serum triglyceride were significant for disabillity outcome in patient with ischemic stroke.

Keywords: Disability, outcome, ischemic stroke

\section{ABSTRAK}

Pendahuluan: Diperkirakan sampai saat ini sekitar 25\% sampai $74 \%$ dari 50 juta pasien stroke yang hidup menjadi tidak mandiri baik membutuhkan bantuan seluruhnya atau hanya sebagian akibat penurunan kemampuan fisik, kognisi, dan emosi.

Tujuan: Untuk mengetahui faktor yang berpengaruh pada luaran disabilitas pasien dengan stroke iskemik.

Metode: Penelitian analitik secara retrospektif berdasarkan data stroke registry dan rekam medis pasien stroke iskemik di RS Bethesda, Yogyakarta, pada tahun 2015-2017. Kriteria inklusi adalah pasien berusia $\geq 40$ tahun yang telah terdiagnosis dengan CT scan kepala, serta memiliki data stroke registry dan rekam medis yang lengkap. Analisis data univariat dan bivariat menggunakan metode Chi-square, serta multivariat dengan metode regresi logistik.

Hasil: Berdasarkan hasil multivariat didapatkan bahwa kekuatan otot 0-4 $(\mathrm{p}=0,023)$, kekuatan otot $3(\mathrm{p}=0,267)$, kekuatan otot $2(\mathrm{p}=0,579)$, kekuatan otot $1(\mathrm{p}=0,049)$, kekuatan otot $0(\mathrm{p}=0,003)$, afasia $(\mathrm{p}<0,001)$, disfagia $(\mathrm{p}<0,001)$, dan kadar trigliserida $(\mathrm{p}=0,043)$ merupakan faktor prediktor yang signifikan terhadap luaran disabilitas pasien stroke iskemik.

Diskusi: Kekuatan otot pasien saat masuk, gejala afasia, disfagia, dan kadar trigliserida berhubungan dengan luaran disabilitas pada pasien stroke iskemik.

Kata kunci: Disabilitas, luaran, stroke iskemik

*FK Universitas Kristen Duta Wacana, Yogyakarta. Korespondensi: drpinzon17@gmail.com.

\section{PENDAHULUAN}

Diperkirakan sampai saat ini sekitar $25 \%$ sampai $74 \%$ dari 50 juta pasien stroke yang hidup menjadi tidak mandiri, baik membutuhkan bantuan seluruhnya atau hanya sebagian saja. Hal ini terjadi baik akibat penurunan kemampuan fisik, kognisi, dan emosi. Berdasarkan skala disabilitas modified Rankin Scale (mRS), Katz dan Barthel mendapatkan bahwa pada 2 tahun pertama pascastroke sebanyak $24-49 \%$ pasien menjadi tidak mandiri, pada tahun ke tiga hingga kelima didapatkan $26-47 \%$ pasien tidak mandiri, dan 10 tahun setelah kejadian stroke terdapat $46 \%$ pasien yang tidak mandiri. ${ }^{1-2}$

Terdapat beberapa faktor berdasarkan penelitian sebelumnya yang dapat memengaruhi luaran dari kejadian stroke seperti hipertensi tidak terkontrol, hiperglikemia, dan inflamasi diperkirakan dapat menyebabkan luaran yang buruk. ${ }^{3}$ Manajemen dan prognosis dari stroke sendiri berkaitan langsung dengan suatu mekanisme spesifik dari stoke iskemik itu sendiri. Prediktor pada kejadian akut berkaitan dengan tingkat keparahan stroke dan usia. Pada stroke 
yang parah biasanya terjadi akibat emboli kardiak dan jarang akibat mekanisme oklusi arteri besar. Status fungsional sebelum onset dari stroke, adanya penyakit komorbid, gangguan kognisi, dan penurunan kesadaran pada kejadian stroke diperkirakan menjadi prediktor luaran stroke meskipun dengan bukti yang lemah. ${ }^{4}$

\section{TUJUAN}

Menemukan faktor yang berperan dalam luaran disabilitas pada pasien dengan stroke iskemik.

\section{METODE}

Penelitian ini dilakukan dengan metode analitik dan desain kohort retrospektif menggunakan rekam medis serta stroke registry. Kriteria inklusi adalah pasien stroke serangan pertama yang telah terdiagnosis dengan CT scan kepala, berusia $\geq 40$ tahun, awitan kurang dari 24 jam, serta memiliki data stroke registry dan rekam medis yang lengkap.

Kesadaran dinilai berdasarkan kualitatif dan Skala Koma Glasgow (SKG) menjadi compos mentis (SKG 15), somnolen (SKG 14-13), sopor (SKG 9-12), dan koma $(\leq 8)$. Penilaian kekuatan motorik dinilai menjadi: 0) lumpuh total; 1) hanya tampak berkontraksi; 2) bergerak ke samping, tidak bisa melawan gravitasi; 3) dapat melawan gravitasi, tidak dapat melawan tahanan ringan; 4) dapat melawan gravitasi, dapat melawan tahanan ringan, tidak dapat melawan tahanan berat; 5) normal. Penilaian luaran menggunakan skala modified Rankin Scale (mRS). Skor $\leq 2$ dianggap mandiri, sebaliknya skor $m R S>2$ tidak mandiri.

Penelitian ini telah disetujui oleh komite etik Fakultas Kedokteran Duta Wacana nomor 496/C.16/ $\mathrm{FK} / 2017$. Analisis data univariat dan bivariat menggunakan metode Chi-square, serta multivariat dengan metode regresi logistik.

\section{HASIL}

Didapatkan 176 subjek (Tabel 1) yang mayoritas (57,4\%) laki-laki, berusia 51-60 tahun, masuk RS dengan awitan 12-24 jam (31,3\%), dan dalam keadaan compos mentis (91,5\%). Defisit neurologis yang paling banyak dikeluhkan adalah hemiparesis (70\%), baik kanan $(38,1 \%)$ maupun kiri
$(30,7 \%)$. Baik afasia maupun disfagia yang berpotensi menyebabkan disabilitas hanya sedikit, yaitu 11,9\% dan 11,4\%. Tekanan darah subjek sebagian besar pada rentang di atas normal untuk sistolik maupun diastolik, termasuk kadar gula darah.

Demikian pula mayoritas subjek tidak mengalami peningkatan kadar kolesterol, riwayat diabetes, atau dislipidemia. Hal ini dapat dilihat dari obat-obat yang digunakan, hanya sebagian kecil yang menggunakan obat-obat antihipertensi, antidiabetes, dan antikoagulan. Obat utama subjek adalah antiplatelet dan statin sesuai dengan pedoman tata laksana stroke. Berdasarkan dari hasil bivariat, didapatkan bahwa kekuatan otot, afasia, disfagia, dan kadar trigliserida memiliki hubungan signifikan dengan luaran disabilitas $(\mathrm{p}<0,05)$.

Analisis multivariat (Tabel 2) dilakukan pada variabel-variabel yang signifikan $(p<0,05)$ sesuai dengan analisis bivariat dan rentang interval kepercayaan (IK) 95\% yang berarti bahwa variabelvariabel tersebut memiliki arti dalam kemungkinan luaran disabilitas pada pasien dengan stroke iskemik. Didapatkan bahwa kekuatan otot $0,1,4$, dan 5, serta afasia, disfagia, dan kadar trigliserida $\geq 200 \mathrm{mg} / \mathrm{dL}$ berhubungan dengan kemandirian. Terutama kekuatan 0 akan menimbulkan ketidakmandirian 20 kali lipat dibandingkan subjek dengan kekuatan 5 secara bermakna $(\mathrm{p}=0,003)$.

\section{PEMBAHASAN}

Pada penelitian ini didapatkan bahwa jumlah perempuan dan laki-laki hampir sama. Sesuai dengan data yang diperoleh dari riset kesehatan dasar bahwa jumlah penderita stroke saat ini sekitar 7,0 per mil yang berdasarkan diagnosis tenaga kesehatan yang akan semakin bertambah angka kejadiannya seiring bertambahnya usia. ${ }^{5}$ Hal serupa ditemukan juga pada penelitian yang dilakukan oleh Bachtiar dkk didapatkan bahwa proporsi pasien laki-laki hampir sama dengan perempuan. ${ }^{9}$

Penelitian ini sesuai dengan penelitian yang sebelumnya yang menyatakan bahwa kehilangan kemampuan motorik akan lebih berpengaruh dibandingkan letak lesi. Hal ini diakibatkan karena kemampuan perbaikan dari kerusakan negatif lebih 
Tabel 1. Karakteristik Subjek dan Analisis Bivariat (n=176)

\begin{tabular}{|c|c|c|c|c|c|c|}
\hline Variabel & $\begin{array}{c}\text { Tidak Mandiri } \\
(\mathrm{n}=34)\end{array}$ & $\begin{array}{l}\text { Mandiri } \\
(n=142)\end{array}$ & n (\%) & RO & IK 95\% & $p^{*}$ \\
\hline $\begin{array}{l}\text { Usia } \\
\text { - } \quad 40-50 \text { tahun } \\
\text { - 51-60 tahun } \\
\text { - 61-70 tahun } \\
\text { - }>70 \text { tahun }\end{array}$ & $\begin{array}{c}4 \\
12 \\
9 \\
9\end{array}$ & $\begin{array}{l}23 \\
47 \\
35 \\
37\end{array}$ & $\begin{array}{l}27(15,3 \%) \\
59(33,5 \%) \\
44(25,0 \%) \\
46(26,1 \%)\end{array}$ & $\begin{array}{c}\text { Ref } \\
1,468 \\
1,479 \\
1,399\end{array}$ & $\begin{array}{l}0,426-5,056 \\
0,407-5,371 \\
0,386-5,069\end{array}$ & 0,934 \\
\hline $\begin{array}{l}\text { Jenis Kelamin } \\
\text { - Laki-laki } \\
\text { - } \quad \text { Perempuan }\end{array}$ & $\begin{array}{l}20 \\
14\end{array}$ & $\begin{array}{l}81 \\
61\end{array}$ & $\begin{array}{c}101(57,4 \%) \\
75(42,6 \%)\end{array}$ & $\begin{array}{c}\text { Ref } \\
0,930\end{array}$ & $0,435-1,987$ & 0,850 \\
\hline $\begin{array}{l}\text { Awitan Masuk RS } \\
\cdot \quad<3 \text { jam } \\
\text { - } 3-6 \text { jam } \\
\text { - } 6-12 \text { jam } \\
\text { - } 12-24 \text { jam }\end{array}$ & $\begin{array}{c}6 \\
7 \\
9 \\
12\end{array}$ & $\begin{array}{l}19 \\
39 \\
41 \\
43\end{array}$ & $\begin{array}{l}25(14,2 \%) \\
46(26,1 \%) \\
50(28,4 \%) \\
55(31,3 \%)\end{array}$ & $\begin{array}{c}\text { Ref } \\
0,568 \\
0,695 \\
0,884\end{array}$ & $\begin{array}{l}0,168-1,926 \\
0,216-2,234 \\
0,289-2,705\end{array}$ & 0,771 \\
\hline $\begin{array}{l}\text { Kesadaran Saat Masuk } \\
\text { RS } \\
\text { - Compos mentis } \\
\text { - Somnolen } \\
\text { - Komatosopor }\end{array}$ & $\begin{array}{c}29 \\
3 \\
2\end{array}$ & $\begin{array}{c}132 \\
8 \\
2\end{array}$ & $\begin{array}{c}161(91,5 \%) \\
11(6,3 \%) \\
4(2,2 \%)\end{array}$ & $\begin{array}{l}\text { Ref } \\
3,695 \\
2,640\end{array}$ & $\begin{array}{l}0,485-28,133 \\
0,247-28,193\end{array}$ & 0,219 \\
\hline $\begin{array}{l}\text { Hemiparesis } \\
\text { - Kiri } \\
\text { - Kanan } \\
\text { - Kanan dan kiri } \\
\text { - Tidak }\end{array}$ & $\begin{array}{c}9 \\
16 \\
0 \\
9\end{array}$ & $\begin{array}{c}45 \\
51 \\
3 \\
43\end{array}$ & $\begin{array}{c}54(30,7 \%) \\
67(38,1 \%) \\
3(1,7 \%) \\
52(29,5 \%)\end{array}$ & $\begin{array}{c}0,956 \\
1,499 \\
0,000 \\
\text { Ref }\end{array}$ & $\begin{array}{l}0,347-2,634 \\
0,602-3,731 \\
0,000-0,000\end{array}$ & 0,574 \\
\hline $\begin{array}{l}\text { Kekuatan Otot } \\
-0 \\
\text { - } 1 \\
\text { - } 2 \\
\text { - } 3 \\
\text { - } 4 \\
\text { - } 5\end{array}$ & $\begin{array}{c}3 \\
6 \\
5 \\
5 \\
5 \\
11\end{array}$ & $\begin{array}{c}1 \\
6 \\
12 \\
16 \\
45 \\
62\end{array}$ & $\begin{array}{c}3(1,7 \%) \\
12(6,8 \%) \\
17(9,7 \%) \\
21(11,9 \%) \\
50(28,4 \%) \\
73(41,5 \%)\end{array}$ & $\begin{array}{c}16,909 \\
4,697 \\
2,348 \\
1,761 \\
0,626 \\
\text { Ref }\end{array}$ & $\begin{array}{c}1,609- \\
177,703 \\
1,219-18,100 \\
0,690-7,991 \\
0,535-5,798 \\
0,203-1,928\end{array}$ & 0,005 \\
\hline $\begin{array}{l}\text { Afasia } \\
\text { - Ya } \\
\text { - } \quad \text { Tidak }\end{array}$ & $\begin{array}{l}10 \\
24\end{array}$ & $\begin{array}{c}11 \\
131\end{array}$ & $\begin{array}{c}21(11,9 \%) \\
115(88,1 \%)\end{array}$ & $\begin{array}{c}4,962 \\
\text { Ref }\end{array}$ & $1,899-12,967$ & $<0,001$ \\
\hline $\begin{array}{l}\text { Kadar GDS } \\
\text { - } \quad<200 \mathrm{gr} / \mathrm{dL} \\
\cdot \quad \geq 200 \mathrm{gr} / \mathrm{dL}\end{array}$ & $\begin{array}{c}6 \\
28\end{array}$ & $\begin{array}{c}28 \\
114\end{array}$ & $\begin{array}{c}20(11,4 \%) \\
156(88,6 \%)\end{array}$ & $\begin{array}{c}\text { Ref } \\
1,146\end{array}$ & $0,433-3,035$ & 0,783 \\
\hline $\begin{array}{l}\text { Disfagia } \\
\text { - Ya } \\
\text { - } \quad \text { Tidak }\end{array}$ & $\begin{array}{l}13 \\
21\end{array}$ & $\begin{array}{c}7 \\
135\end{array}$ & $\begin{array}{c}142(80,7 \%) \\
34(19,3 \%)\end{array}$ & $\begin{array}{c}11,939 \\
\text { Ref }\end{array}$ & $4,273-33,356$ & $<0,001$ \\
\hline $\begin{array}{l}\text { Fibrilasi Atrium } \\
\text { - Ya } \\
\text { - Tidak }\end{array}$ & $\begin{array}{c}2 \\
32\end{array}$ & $\begin{array}{c}1 \\
141\end{array}$ & $\begin{array}{c}3(1,7 \%) \\
173(98,3 \%)\end{array}$ & $\begin{array}{c}8,813 \\
\text { Ref }\end{array}$ & $\begin{array}{c}0,775- \\
100,194\end{array}$ & 0,036 \\
\hline $\begin{array}{l}\text { Antiplatelet } \\
\text { - Ya } \\
\text { - Tidak }\end{array}$ & $\begin{array}{c}33 \\
1\end{array}$ & $\begin{array}{c}138 \\
4\end{array}$ & $\begin{array}{c}171(97,2 \%) \\
5(2,8 \%)\end{array}$ & $\begin{array}{l}\text { Ref } \\
0,957\end{array}$ & $0,103-8,842$ & 0,969 \\
\hline $\begin{array}{l}\text { Antikoagulan } \\
\text { - Ya } \\
\text { - Tidak }\end{array}$ & $\begin{array}{c}5 \\
29\end{array}$ & $\begin{array}{c}11 \\
131\end{array}$ & $\begin{array}{c}16(9,1 \%) \\
160(90,9 \%)\end{array}$ & $\begin{array}{c}2,053 \\
\text { Ref }\end{array}$ & $0,663-6,363$ & 0,205 \\
\hline $\begin{array}{l}\text { Statin } \\
\text { - Ya } \\
\text { - Tidak }\end{array}$ & $\begin{array}{l}22 \\
12\end{array}$ & $\begin{array}{l}78 \\
64\end{array}$ & $\begin{array}{c}100(56,8 \%) \\
76(43,2 \%)\end{array}$ & $\begin{array}{l}1,504 \\
\text { Ref }\end{array}$ & $0,692-3,272$ & 0,301 \\
\hline
\end{tabular}




\begin{tabular}{|c|c|c|c|c|c|c|}
\hline $\begin{array}{l}\text { Antikoagulan } \\
\text { - Ya } \\
\text { - Tidak }\end{array}$ & $\begin{array}{c}5 \\
29\end{array}$ & $\begin{array}{c}11 \\
131\end{array}$ & $\begin{array}{c}16(9,1 \%) \\
160(90,9 \%)\end{array}$ & $\begin{array}{c}2,053 \\
\text { Ref }\end{array}$ & $0,663-6,363$ & 0,205 \\
\hline $\begin{array}{l}\text { Statin } \\
\text { - Ya } \\
\text { - Tidak }\end{array}$ & $\begin{array}{l}22 \\
12\end{array}$ & $\begin{array}{l}78 \\
64\end{array}$ & $\begin{array}{c}100(56,8 \%) \\
76(43,2 \%)\end{array}$ & $\begin{array}{c}1,504 \\
\text { Ref }\end{array}$ & $0,692-3,272$ & 0,301 \\
\hline $\begin{array}{l}\text { Antihipertensi } \\
\text { - Ya } \\
\text { - Tidak }\end{array}$ & $\begin{array}{l}11 \\
23\end{array}$ & $\begin{array}{l}51 \\
91\end{array}$ & $\begin{array}{c}62(35,2 \%) \\
114(64,8 \%)\end{array}$ & $\begin{array}{c}0,853 \\
\text { Ref }\end{array}$ & $0,385-1,892$ & 0,696 \\
\hline $\begin{array}{l}\text { Antidiabetik } \\
\text { - Ya } \\
\text { - Tidak }\end{array}$ & $\begin{array}{c}4 \\
30\end{array}$ & $\begin{array}{c}27 \\
115\end{array}$ & $\begin{array}{c}31(17,6 \%) \\
145(82,4 \%)\end{array}$ & $\begin{array}{c}0,568 \\
\text { Ref }\end{array}$ & $0,184-1,748$ & 0,319 \\
\hline $\begin{array}{l}\text { Tekanan Sistolik } \\
\text { - } \quad<129 \mathrm{mmHg} \\
\text { - } 130-139 \mathrm{mmHg} \\
\text { - } \geq 140 \mathrm{mmHg}\end{array}$ & $\begin{array}{c}4 \\
3 \\
27\end{array}$ & $\begin{array}{c}15 \\
12 \\
115\end{array}$ & $\begin{array}{c}19(10,8 \%) \\
15(8,5 \%) \\
142(80,7 \%)\end{array}$ & $\begin{array}{c}\text { Ref } \\
0,938 \\
0,880\end{array}$ & $\begin{array}{l}0,175-5,022 \\
0,271-2,865\end{array}$ & 0,976 \\
\hline $\begin{array}{l}\text { Tekanan Diastolik } \\
\text { - } \quad<84 \mathrm{mmHg} \\
\text { - } \quad \geq 90 \mathrm{mmHg}\end{array}$ & $\begin{array}{l}10 \\
24\end{array}$ & $\begin{array}{c}39 \\
103\end{array}$ & $\begin{array}{c}49(27,8 \%) \\
127(72,2 \%)\end{array}$ & $\begin{array}{c}\text { Ref } \\
0,909\end{array}$ & $0,398-2,073$ & 0,820 \\
\hline 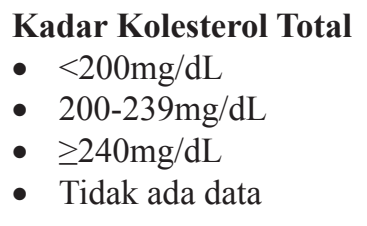 & $\begin{array}{c}9 \\
2 \\
4 \\
19\end{array}$ & $\begin{array}{l}32 \\
29 \\
20 \\
61\end{array}$ & $\begin{array}{l}41(23,3 \%) \\
31(17,6 \%) \\
24(13,6 \%) \\
40(45,5 \%)\end{array}$ & $\begin{array}{c}\text { Ref } \\
0,245 \\
0,711 \\
1,107\end{array}$ & $\begin{array}{l}0,049-1,230 \\
0,193-2,619 \\
0,450-2,727\end{array}$ & 0,204 \\
\hline $\begin{array}{l}\text { Kadar LDL } \\
\text { - } \quad<130 \mathrm{mg} / \mathrm{dL} \\
\text { - } \quad \geq 130 \mathrm{mg} / \mathrm{dL} \\
\text { - } \quad \text { Tidak ada data }\end{array}$ & $\begin{array}{c}2 \\
10 \\
22\end{array}$ & $\begin{array}{l}28 \\
41 \\
73\end{array}$ & $\begin{array}{l}30(17 \%) \\
51(29 \%) \\
95(54 \%)\end{array}$ & $\begin{array}{c}\text { Ref } \\
3,789 \\
1,118\end{array}$ & $\begin{array}{c}0,821-17,478 \\
0,471-2,652\end{array}$ & 0,137 \\
\hline $\begin{array}{l}\text { Kadar HDL } \\
\text { - } \quad<40 \mathrm{mg} / \mathrm{dL} \\
\text { - } \quad 40-59 \mathrm{mg} / \mathrm{dL} \\
\text { - } \quad \geq 60 \mathrm{mg} / \mathrm{dL} \\
\text { - } \quad \text { Tidak ada data }\end{array}$ & $\begin{array}{c}4 \\
2 \\
1 \\
27\end{array}$ & $\begin{array}{c}20 \\
21 \\
2 \\
99\end{array}$ & $\begin{array}{c}24(13,6 \%) \\
23(13,1 \%) \\
3(1,7 \%) \\
126(71,6 \%)\end{array}$ & $\begin{array}{c}\text { Ref } \\
0,476 \\
2,500 \\
1,364\end{array}$ & $\begin{array}{c}0,078-2,894 \\
0,180-34,669 \\
0,430-4,327\end{array}$ & 0,473 \\
\hline $\begin{array}{l}\text { Kadar Trigliserida } \\
\text { - } \quad<200 \mathrm{mg} / \mathrm{dL} \\
\text { - } \geq 200 \mathrm{mg} / \mathrm{dL} \\
\text { - } \quad \text { Tidak ada data }\end{array}$ & $\begin{array}{c}11 \\
1 \\
22\end{array}$ & $\begin{array}{l}51 \\
23 \\
68\end{array}$ & $\begin{array}{l}62(35,2 \%) \\
24(13,6 \%) \\
90(51,1 \%)\end{array}$ & $\begin{array}{c}\text { Ref } \\
0,202 \\
1,500\end{array}$ & $\begin{array}{l}0,025-1,655 \\
0,667-3,371\end{array}$ & 0,037 \\
\hline $\begin{array}{l}\text { Riwayat Hipertensi } \\
\text { - Ya } \\
\text { - Tidak }\end{array}$ & $\begin{array}{l}14 \\
20\end{array}$ & $\begin{array}{l}72 \\
70\end{array}$ & $\begin{array}{l}86(48,9 \%) \\
90(51,1 \%)\end{array}$ & $\begin{array}{c}0,681 \\
\text { Ref }\end{array}$ & $0,319-1,452$ & 0,318 \\
\hline $\begin{array}{l}\text { Riwayat Dislipidemia } \\
\text { - Ya } \\
\text { - Tidak }\end{array}$ & $\begin{array}{l}12 \\
22\end{array}$ & $\begin{array}{l}52 \\
90\end{array}$ & $\begin{array}{c}64(36,4 \%) \\
112(63,6 \%)\end{array}$ & $\begin{array}{c}0,944 \\
\text { Ref }\end{array}$ & $0,432-2,063$ & 0,885 \\
\hline $\begin{array}{l}\text { Riwayat Diabetes } \\
\text { - Ya } \\
\text { - Tidak }\end{array}$ & $\begin{array}{c}4 \\
30\end{array}$ & $\begin{array}{c}26 \\
116\end{array}$ & $\begin{array}{c}30(17,0 \%) \\
146(83,0 \%)\end{array}$ & $\begin{array}{c}0,595 \\
\text { Ref }\end{array}$ & $0,193-1,835$ & 0,362 \\
\hline
\end{tabular}

terbatas dibandingkan kerusakan positif setelah episode stroke. ${ }^{3}$ Kehilangan kekuatan yang ringan
(MRC $\geq 3$ ) dapat memprediksi luaran indeks Barthel yang lebih baik dibandingkan yang memiliki paresis 
Tabel 2. Analisis Multivariat $(n=176)$

\begin{tabular}{lccc}
\hline \multicolumn{1}{c}{ Variabel } & RO & IK 95\% & $\mathbf{p}^{*}$ \\
\hline Kekuatan Otot & & & \\
$\bullet \quad 0$ & 20,162 & $1,675-$ & 0,003 \\
$\bullet \quad 1$ & 4,765 & 242,721 & 0,049 \\
$\bullet \quad 2$ & 0,610 & $0,979-23,204$ & 0,579 \\
$\bullet \quad 3$ & 3,811 & $0,097-3,840$ & 0,267 \\
$\bullet \quad 4$ & 1,097 & $0,953-15,240$ & 0,023 \\
-5 & Ref & $0,320-3,767$ & 0,004 \\
Afasia & 3,438 & $0,947-12,488$ & $<0,001$ \\
Disfagia & 11,044 & $3,191-12,488$ & $<0,001$ \\
Kadar Trigliserida & & & \\
$\bullet \quad<200 \mathrm{mg} / \mathrm{dL}$ & Ref & & 0,076 \\
- $\geq 200 \mathrm{mg} / \mathrm{dL}$ & 0,189 & $0,020-1,802$ & 0,043 \\
\hline
\end{tabular}

*Uji regresi logistik. IK: interval kepercayaan; RO: rasio Odds.

yang cukup serius terutama pada episode akut. Tetapi luas lesi pada MRI tidak memengaruhi luaran. ${ }^{6}$

Berdasarkan hasil penelitian ini, semakin menurunnya kekuatan otot pada pasien saat masuk kemungkinan subjek untuk menjadi disabilitas menjadi lebih tinggi. Hal ini dapat dilihat pada subjek yang memiliki $\mathrm{mRS}>2$ sebagian besar mengalami penurunan kekuatan otot saat evaluasi pertama. Penurunan kekuatan otot ini dikaitkan dengan meluasnya kerusakan pada area motorik otak yang memengaruhi sistem penghantaran impuls ke otot.

Afasia terutama global afasia memengaruhi luaran dari pasien stroke iskemik. ${ }^{7}$ Global afasia sendiri menjadi prediktor prognosis yang buruk yang kemungkinan diakibatkan terlibatnya gangguan pada daerah vaskularisasi perisilvian yang terletak pada daerah arteri serebri media. ${ }^{8}$ Afasia merupakan salah satu disabilitas yang sering terjadi dan dapat menghambat proses rehabilitasi pada pasien pascastroke. ${ }^{9}$ Pada penelitian ini didapatkan hasil yang signifikan terhadap afasia sebagai salah satu faktor prediksi disabilitas pasien stroke iskemik.

Afasia pada pasien stroke iskemik terutama berbentuk sebagai afasia global yang merupakan percampuran antara afasia Wernicke dan afasia Broca yang ditunjukan dengan gejala mutisme atau pasien hanya mengatakan beberapa kata singkat. Afasia sendiri dikaitkan dengan adanya emboli pada arteri serebri media yang tepatnya pada hemisfer kiri.

Disfagia sebagai faktor prognosis buruk luaran disfagia pada pasien dengan stroke iskemik dikaitkan dengan komplikasi yang erat berkaitan dengan keadaan disfagia, yaitu kondisi malnutrisi, dehidrasi, dan komplikasi penyakit paru. ${ }^{10} \mathrm{Hal}$ ini akibat lesi pada korteks serebral atau batang otak yang memungkinkan terjadinya aspirasi dan disfagia, sesuai dengan penelitian ini bahwa disfagia merupakan salah satu faktor prediktor disabilitas.

Tingginya kadar trigliserida puasa saat masuk RS memiliki prognosis baik, tetapi tidak pada penyakit lain, walaupun mekanisme penyebabnya belum diketahui. ${ }^{11}$ Hal ini dibuktikan dengan rendahnya kemungkinan disabilitas dan kematian 3 bulan, ${ }^{12}$ sesuai dengan penelitian ini bahwa tingginya kadar trigliserida memberikan prognosis yang baik.

Penelitian ini dilakukan dengan metode kohort retrospektif dengan menggunakan data sekunder, sehingga penelitian ini terbatas karena peneliti tidak dapat mengontrol keadaan dan kualitas dari pengukuran oleh orang lain pada masa lampau.

\section{KESIMPULAN}

Kekuatan otot pasien saat masuk, gejala afasia, disfagia, dan kadar trigliserida berhubungan dengan luaran disabilitas pada pasien stroke iskemik.

\section{DAFTAR PUSTAKA}

1. Sacco RL, Kasner SE, Broderick JP, Caplan LR, Connors JJ, Culebras A, dkk. An updated definition of stroke for the 21st century a statement for healthcare professionals from the American heart. Stroke. 2013;44(7):2064-89.

2. Carmo JF, Morelato RL, Pinto HP, Oliveira ER. Disability after stroke: a systematic review. Fisioter. 2015;28(2):407-18.

3. Canning CG, Ada L, Adams R, O’Dwyer NJ. Loss of strength contributes more to physical disability after stroke than loss of dexterity. Clin Rehabil. 2004; 18(3):300-8.

4. Corso G, Bottacchi E, Tosi P, Caligiana L, Lia C, Morosini MV, dkk. Outcome predictors in firstever ischemic stroke patients: a population-based study. International Scholarly Research Notices. 2014;2014:1-8.

5. Hasil Riset Kesehatan Dasar. Jakarta: Badan Riset Kesehatan Kementrian Kesehatan Indonesia Badan Riset Kesehatan Kementrian Kesehatan Indonesia. 2013;2013:9.

6. Chi N, Ku H, Chen D, Tseng Y, Chen C, Lin Y, dkk. Cerebral motor functional connectivity at the acute stage: an outcome predictor of ischemic stroke. Sci Rep. 2018;8(1):1-8. 
7. Paolucci S. Epidemiology and treatment of poststroke depression. Neuropsychiatr Dis Treat. 2008;4(1):145-54.

8. Oliveira FF, Damasceno BP. Global aphasia as a predictor of mortality in the acute phase of a first stroke. Arq Neuropsiquiatr. 2010;69(2B):277-82.

9. Bachtiar V, Ong P, Gamayani U, Amalia L, Aminah S. Kejadian afasia pada stroke fase akut dan perubahan sindrom afasia pascastroke. Neurona. 2018;35(4):232-8.

10. Padma RG, Pinzon RT, Pramudita EA. Kejadian disfagia saat masuk rumah sakit sebagai faktor prognosis buruk luaran klinis pasien stroke iskemik. CDK-248. 2017;4:7-11.

11. Pikija S, Trkulja V, Juvan L, Ivanec M, Duksi D. Higher on-admission serum triglycerides predict less severe disability and lower all-cause mortality after acute ischemic stroke. J Stroke Cerebrovasc Dis. 2013;22:e15-24.

12. Kang K, Lee JJ, Park JM, Kwon O, Han SW, Kim BK. High nonfasting triglyceride concentrations predict good outcome following acute. Neurological Research. 2017;39(9):779-86. 